$\begin{array}{ll}\text { Abstracta Iranica } & \begin{array}{l}\text { Abstracta Iranica } \\ \text { Revue bibliographique pour le domaine irano-aryen }\end{array} \\ & \text { Volume } 22 \mid \mathbf{2 0 0 1} \\ & \text { Comptes rendus des publications de } 1999\end{array}$

\title{
Žabpānga. Peshawar, 1998, 637p. [Réserve langagière]
}

\section{Nadjib Manalaï}

\section{(2) OpenEdition}

1 Journals

\section{Édition électronique}

URL : http://journals.openedition.org/abstractairanica/37194

DOI : 10.4000/abstractairanica.37194

ISSN : 1961-960X

Éditeur :

CNRS (UMR 7528 Mondes iraniens et indiens), Éditions de l'IFRI

\section{Édition imprimée}

Date de publication : 15 mai 2001

ISSN : 0240-8910

\section{Référence électronique}

Nadjib Manalaï, «Žəbpānga. Peshawar, 1998, 637p. [Réserve langagière] », Abstracta Iranica [En ligne], Volume 22 | 2001, document 581, mis en ligne le 17 février 2010, consulté le 13 octobre 2020. URL http://journals.openedition.org/abstractairanica/37194; DOI : https://doi.org/10.4000/ abstractairanica.37194

Ce document a été généré automatiquement le 13 octobre 2020.

Tous droits réservés 


\section{Žzbpānga. Peshawar, 1998, 637p. [Réserve langagière]}

Nadjib Manalaï

1 Environ 2000 mots (archaïsmes et particularismes régionaux) de la littérature pachto sont expliqués et illustrés avec des exemples tirés des plus grands auteurs. Les mots sont donnés en graphie pachto et en transcription.

2 Pour des mots relativement courants l'A. se contente de mettre en avant les seules acceptions peu familières. Certains mots dont l'A. n'a pas trouvé la signification exacte sont donnés avec les seuls exemples tirés de la littérature.

\section{INDEX}

Thèmes : 11.2. Littérature pashto et dari (Afghanistan)

\section{AUTEURS}

NADJIB MANALAÏ

INALCO - Paris 